\title{
Geothrix fermentans gen. nov., sp. nov., a novel Fe(III)-reducing bacterium from a hydrocarbon-contaminated aquifer
}

\author{
John D. Coates, ${ }^{1}$ Debra J. Ellis, ${ }^{2}+$ Catherine V. Gaw ${ }^{2}$ and Derek R. Lovley ${ }^{2}$
}

Author for correspondence: John D. Coates. Tel: +1 618453 6132. Fax: + 16184538036. e-mail: jcoates@micro.siu.edu

1 Department of Microbiology, Southern Illinois University, Carbondale, IL 62901, USA

2 Department of Microbiology, University of Massachusetts, Amherst, MA 01003, USA

\begin{abstract}
In an attempt to understand better the micro-organisms involved in anaerobic degradation of aromatic hydrocarbons in the Fe(III)-reducing zone of petroleum-contaminated aquifers, Fe(III)-reducing micro-organisms were isolated from contaminated aquifer material that had been adapted for rapid oxidation of toluene coupled to Fe(III) reduction. One of these organisms, strain $\mathrm{H}^{-5^{\top}}$, was enriched and isolated on acetate/Fe(III) medium. Strain $\mathrm{H}^{-5^{\top}}$ is a Gram-negative strict anaerobe that grows with various simple organic acids such as acetate, propionate, lactate and fumarate as alternative electron donors with $\mathrm{Fe}$ (III) as the electron acceptor. In addition, strain $\mathrm{H}^{-5^{\top}}$ also oxidizes long-chain fatty acids such as palmitate with Fe(III) as the sole electron acceptor. Strain $\mathrm{H}-5^{\top}$ can also grow by fermentation of citrate or fumarate in the absence of an alternative electron acceptor. The primary endproducts of citrate fermentation are acetate and succinate. In addition to various forms of soluble and insoluble Fe(III), strain $\mathrm{H}^{\top} 5^{\top}$ grows with nitrate, Mn(IV), fumarate and the humic acid analogue 2,6-anthraquinone disulfonate as alternative electron acceptors. As with other organisms that can oxidize organic compounds completely with the reduction of Fe(III), cell suspensions of strain $\mathrm{H}^{-5^{\top}}$ have absorbance maxima indicative of a c-type cytochrome(s). It is proposed that strain $\mathrm{H}^{-5^{\top}}$ represents a novel genus in the HolophagaAcidobacterium phylum and that it should be named Geothrix fermentans sp. nov., gen. nov.
\end{abstract}

Keywords: $\mathrm{Fe}(\mathrm{III})$ reduction, humic acid reduction, toluene degradation, Acidobacterium, Holophaga

\section{INTRODUCTION}

Dissimilatory $\mathrm{Fe}(\mathrm{III})$-reducing bacteria (DIRB) conserve energy to support growth by coupling the oxidation of organic compounds and/or $\mathrm{H}_{2}$ to the reduction of ferric iron (Lovley et al., 1997). Dissimilatory $\mathrm{Fe}(\mathrm{III})$ reduction may have been one of the first globally significant processes for the oxidation of organic matter to $\mathrm{CO}_{2}$ (Walker, 1987; Lovley, 1991; Vargas et al., 1998) and has a significant role in

†Present address: Department of Biology, University of Massachusetts, Dartmouth, MA, USA.

Abbreviations: AQDS, 2,6-anthraquinoline disulfonate; DIRB, dissimilatory Fe(III)-reducing bacteria; NTA, nitrilotriacetic acid.

The GenBank accession number for the 165 rDNA sequence of Geothrix fermentans strain $\mathrm{H}-5^{\top}$ is $\mathrm{U} 41563$. modern sedimentary environments, not only in the oxidation of organic matter (Lovley, 1995), but also in the dissolution of iron(III) oxides and the formation of geologically significant minerals such as magnetite and siderite (Lovley et al., 1987; Coleman et al., 1993; Lovley, 1995). DIRB have been recovered from a wide variety of sedimentary environments including freshwater and marine aquatic sediments, the deep terrestrial subsurface, petroleum-contaminated aquifers, soils and hydrothermal zones (Lovley et al., 1997; Vargas et al., 1998).

Fe(III)-reducing bacteria are both phenotypically and taxonomically diverse (Lovley et al., 1997; Vargas et al., 1998). They fall into two basic physiological categories, those that oxidize multicarbon compounds completely to $\mathrm{CO}_{2}$ and those that oxidize multicarbon compounds incompletely to acetate. The complete 
oxidizers include members of the family Geobacteraceae (Lonergan et al., 1996) in the $\delta$-subclass of the Proteobacteria, such as species from the genera Geobacter (Lovley et al., 1993; Caccavo et al., 1994; Coates et al., 1996), Desulfuromonas (Roden \& Lovley, 1993; Coates et al., 1995) and Desulfuromusa (Finster \& Bak, 1993; Lonergan et al., 1996), as well as phylogenetically distinct genera such as Geovibrio (Caccavo et al., 1996) and the recently described Deferribacter (Greene et al., 1997). The incomplete oxidizers include organisms in the genera Shewanella (Lovley et al., 1989b; Caccavo et al., 1992; RosselloMora et al., 1994; Coates et al., 1998b), Ferrimonas (Rossello-Mora et al., 1995), Pelobacter (Lovley et al., 1995) and Thermoterrabacterium (Slobodkin et al., 1997), as well as the organism known as strain SES-3 (Laverman et al., 1995). All of the incompletely oxidizing, but only a few of the completely oxidizing, DIRB can use $\mathrm{H}_{2}$ (Lovley et al., 1997). All of the Fe(III)-reducing hyperthermophilic Archaea and Bacteria that have been examined to date also have the ability to oxidize $\mathrm{H}_{2}$ with $\mathrm{Fe}$ (III) (Vargas et al., 1998).

In order to learn more about the diversity and metabolic capabilities of DIRB, we investigated DIRB populations in the $\mathrm{Fe}(\mathrm{III})$-reducing zone of petroleumcontaminated aquifers. $\mathrm{Fe}$ (III) reduction has previously been shown to be an important terminal electron-accepting process in such environments (Lovley et al., 1989a ; Lovley, 1997), but little is know about the DIRB populations that inhabit these systems. The most readily isolated Fe(III)-reducers from mesophilic environments belong to the family Geobacteraceae in the $\delta$-subclass of the Proteobacteria (Lonergan et al., 1996) and are usually species of the genus Geobacter (Coates et al., 1996). However, a recent study (Anderson et al., 1998), using densitygradient gel electrophoresis coupled to most-probablenumber counts, on the $\mathrm{Fe}$ (III)-reducing population of a hydrocarbon-contaminated aquifer indicated that another, as yet undescribed, class of DIRB was dominant in the pristine portion of the aquifer and equivalent in numbers to the Geobacter species in the contaminated $\mathrm{Fe}(\mathrm{III})$-reducing zone of the aquifer. Here, we report on the first isolate of this new group of DIRB. This organism was isolated from the Fe(III)reducing zone of a petroleum-contaminated aquifer. This organism has a physiology distinct from all other known DIRB and is a member of the recently recognized Holophaga-Acidobacterium phylum.

\section{METHODS}

Source of organism. Strain $\mathrm{H}-5^{\mathrm{T}}$ was isolated from sediments that had been used to study the effects of nitrilotriacetic acid (NTA) on aromatic hydrocarbon degradation in petroleumcontaminated aquifers (Lovley et al., 1994b). The sediments had been collected from a petroleum-contaminated aquifer at the Defense Fuel Supply Center in Hanahan, SC, USA. The sediments were from site MW 20, which is within a zone in which $\mathrm{Fe}$ (III) reduction is the terminal electron-accepting process (Lovley et al., 1994a, b). In anoxic laboratory
Table 1. Compounds tested as electron donors

Compounds were tested in the presence of iron(III) NTA $(10 \mathrm{mM})$ at the concentrations given in parentheses.

\begin{tabular}{|ll|}
\hline \multicolumn{1}{|c|}{ Utilized } & \multicolumn{1}{c|}{ Not utilized } \\
\hline Acetate $(10 \mathrm{mM})$ & Formate $(10 \mathrm{mM})$ \\
Propionate $(5 \mathrm{mM})$ & $\mathrm{H}_{2}(101 \mathrm{kPa})$ \\
Palmitate $(1.0 \mathrm{mM})$ & Methanol $(10 \mathrm{mM})$ \\
Succinate $(1.0 \mathrm{mM})$ & Ethanol $(10 \mathrm{mM})$ \\
Fumarate $(10 \mathrm{mM})$ & Phenol $(0.5 \mathrm{mM})$ \\
Lactate $(10 \mathrm{mM})$ & Toluene $(1.0 \mathrm{mM})$ \\
Yeast extract $\left(1 \mathrm{~g} \mathrm{l}^{-1}\right)$ & Benzene $(1.0 \mathrm{mM})$ \\
& Hexadecane $(1.0 \mathrm{mM})$ \\
& Benzoate $(0.5 \mathrm{mM})$ \\
& Glucose $(10 \mathrm{mM})$ \\
& Glycerol $(10 \mathrm{mM})$ \\
\hline
\end{tabular}

incubations, the sediments were amended with NTA (about 2 mmol NTA kg-1 sediment) and toluene (about $10 \mu \mathrm{M}$ ) as described previously (Lovley et al., 1994b). The sediments were refed with toluene when it was depleted. When sediments were well adapted for high rates of toluene oxidation coupled to $\mathrm{Fe}$ (III) reduction, a sample of the sediments ( $1 \mathrm{~g})$ was used to establish enrichment cultures with acetate as the sole electron donor and iron(III) NTA as the electron acceptor.

Culturing on $\mathrm{Fe}(\mathrm{III})$. Standard anaerobic culturing techniques were used throughout (Hungate, 1969; Miller \& Wolin, 1974; Balch et al., 1979). The medium was boiled under $\mathrm{N}_{2} / \mathrm{CO}_{2}(80: 20)$ to remove dissolved $\mathrm{O}_{2}$ and then dispensed into anaerobic pressure tubes or serum bottles under $\mathrm{N}_{2} / \mathrm{CO}_{2}$, capped with thick butyl-rubber stoppers and sterilized by autoclaving. The basal medium was the bicarbonate-buffered freshwater medium that had been used previously to isolate Geobacter species (Coates et al., 1996). Unless otherwise noted, acetate $(10 \mathrm{mM})$ was the electron donor. Soluble Fe(III) (10 mM) was supplied as iron(III) citrate (Lovley \& Phillips, 1988b), iron(III) pyrophosphate (Caccavo et al., 1994; Coates et al., 1996) or iron(III) NTA (Roden \& Lovley, 1993). Poorly crystalline iron(III) oxide was prepared as described previously (Lovley \& Phillips, 1986) and provided at $100 \mathrm{mmol} \mathrm{l}^{-1}$ medium.

Purified agar $(2 \% \mathrm{w} / \mathrm{v})$ was included to prepare agar plates, which were poured under an atmosphere of $\mathrm{N}_{2} / \mathrm{CO}_{2} / \mathrm{H}_{2}$ $(85: 5: 10)$ in an anaerobic chamber. Plates were incubated under a positive pressure $(100 \mathrm{kPa})$ of $\mathrm{N}_{2} / \mathrm{CO}_{2}(80: 20)$ in sealed aluminium chambers similar to those described previously (Balch et al., 1979). All incubations were at $30^{\circ} \mathrm{C}$ unless otherwise noted.

Alternative electron donors and acceptors. Alternative electron donors were added from sterile, anoxic stock solutions at concentrations listed in Table 1 , as described previously (Coates et al., 1996). $\mathrm{H}_{2}$ was added directly to the headspace of sealed vials by syringe to give a final partial pressure of $101 \mathrm{kPa}$. When noted, alternative electron acceptors to Fe(III) were added to basal medium from sterile, anoxic stock solutions in the form of sodium salts of nitrate, thiosulfate, sulfate, selenate, fumarate or malate at concentrations outlined in Table 1. Elemental sulfur was added in the form of polysulfide from a sterile, anoxic stock as 
described previously (Coates et al., 1998a). Basal medium containing the humic acid analogue 2,6 anthraquinone disulfonate (AQDS) $(5 \mathrm{mM})$ as the sole electron acceptor was prepared as described previously (Coates et al., 1998a) in order to evaluate the ability of strain $\mathrm{H}-5^{\mathrm{T}}$ to couple the oxidation of carbon to the reduction of humic substances (Lovley et al., 1996, 1998; Coates et al., 1998a).

Cytochrome content. As a preliminary investigation of the cytochrome content of strain $\mathrm{H}-5^{\mathrm{T}}$, dithionite-reduced versus air-oxidized difference spectra were obtained on washed cell suspensions of lactate/fumarate-grown cells in bicarbonate buffer as described previously (Lovley et al., 1993; Coates et al., 1996).

Scanning electron microscopy. Cells of strain $\mathrm{H}-5^{T}$ for scanning electron microscopy were grown on lactate/ fumarate medium and filtered onto $0.2 \mu \mathrm{m}$ pore-size filters. The samples were fixed for $2 \mathrm{~h}$ in $2 \%(\mathrm{v} / \mathrm{v})$ glutaraldehyde and washed three times, for $20 \mathrm{~min}$ per wash, in $0.1 \mathrm{M}$ sodium cacodylate. The fixed samples were successively dehydrated with ethanol and stored overnight at $4{ }^{\circ} \mathrm{C}$ in $100 \%$ ethanol. These samples were dried by critical-point drying, coated with gold/palladium and examined with a Cambridge 250 MK3 scanning electron microscope at $21 \mathrm{kV}$.

$16 S$ rRNA gene sequencing and analysis. Nucleic acids were isolated from a cell pellet of strain $\mathrm{H}-5^{\mathrm{T}}$ and the nearly complete $16 \mathrm{~S}$ rDNA was amplified and purified, as described previously (Lonergan et al., 1996). Sequencing of both strands of the 16S rDNA was performed at the Michigan State University Sequencing Facility using eubacterial 16S rDNA sequencing primers on a 373A DNA sequencing system (Applied Biosystems).

The $\mathrm{H}-5^{\mathrm{T}}$ 16S rDNA and other sequences used in the phylogenetic analysis were aligned manually to sequences obtained from the Ribosomal Database Project (Maidak et al., 1997). Evolutionary distances, computed as described previously (Jukes \& Cantor, 1969), were used to construct a distance tree by the De Soete least-squares algorithm (De Soete, 1983).

The GenBank and EMBL accession numbers for sequences used in the phylogenetic analysis were: Acidobacterium capsulatum, D26171; Aeromonas hydrophila, M59148; Clostridium pasteurianum, M23930; Deferribacter thermophilus, U75602; 'Desulfuromonas palmitatis', U28172; Desulfuromusa bakii, X79412; Ferrimonas balearica, X93021; Geobacter metallireducens, L07834; 'Geovibrio ferrireducens', X95744; Holophaga foetida, X77215; Pelobacter carbinolicus, U23141; Shewanella alga, X81622; Shewanella putrefaciens, X81623; strain SES-3, U41564; Thermoterrabacterium ferrireducens, U76363; and Wolinella succinogenes, M88159.

Analytical techniques. As described previously, Fe(III) reduction was monitored spectrophotometrically by ferrozine assay of HCl-extractable Fe(II) (Lovley \& Phillips, 1986) or soluble Fe(II) (Lovley \& Phillips, 1988a). Direct cell counts were done by epifluorescent microscopy of acridine-orangestained samples (Hobbie et al., 1977). Growth of cultures on soluble electron acceptors was monitored by inserting the culture tubes directly into a Spectronic 20 spectrophotometer (Spectronic Instruments) and measuring optical density at $600 \mathrm{~nm}$. Sulfide was analysed colorimetrically with the methylene blue method as described previously (Cline, 1969). Concentrations of organic acids in culture broths were determined by HPLC as described previously
(Lovley \& Phillips, 1989) with UV detection at $210 \mathrm{~nm}$. The concentration of the reduced product of AQDS, 2,6anthrahydroquinone disulfonate, was determined spectrophotometrically at $450 \mathrm{~nm}$ as described previously (Lovley et al., 1996).

\section{RESULTS}

\section{Enrichment and isolation}

After three successive transfers (10\% inoculum) of the acetate-oxidizing, Fe(III)-reducing enrichment culture, the third transfer was streaked onto agar plates of acetate/iron(III) pyrophosphate medium (Caccavo et al., 1994; Coates et al., 1996). Fe(III)reducing colonies were recognized easily, as their growth resulted in clearing zones around the colonies in the green-coloured iron(III) pyrophosphate medium

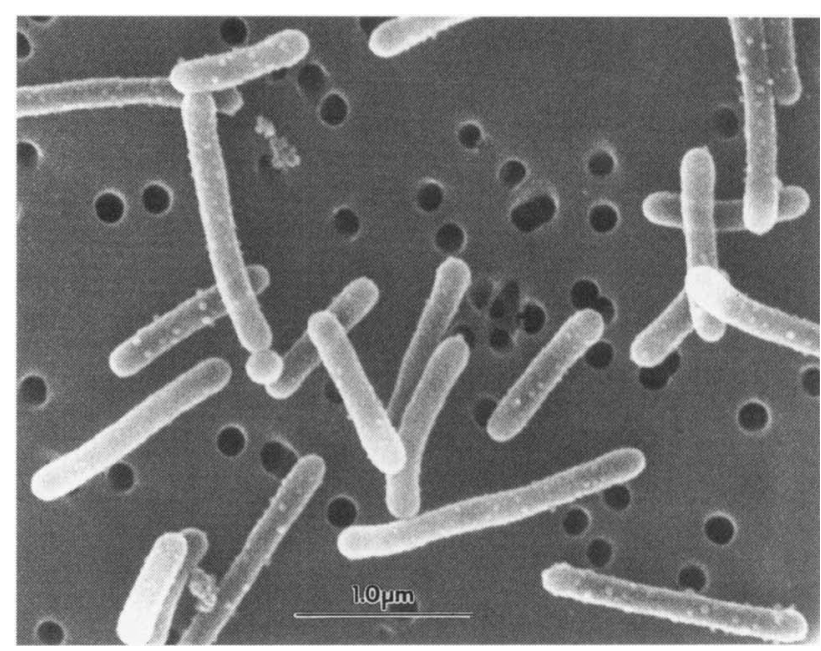

Fig. 1. Scanning electron micrograph of cells of strain $\mathrm{H}-5^{\top}$. Bar, $1 \mu \mathrm{m}$.

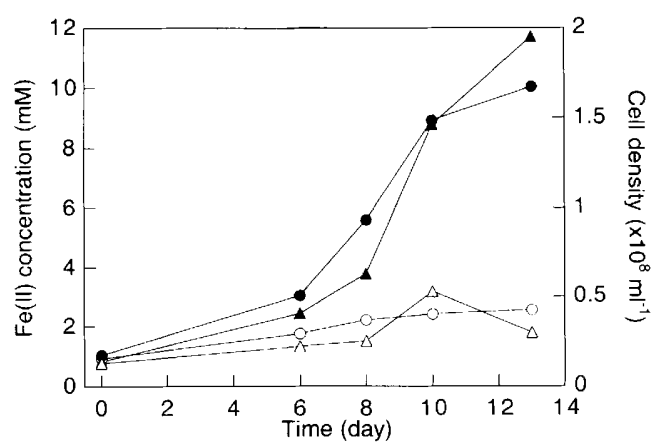

Fig. 2. Growth and $\mathrm{Fe}(\mathrm{III})$ reduction by strain $\mathrm{H}-5^{\top}$ with palmitate as the electron donor. (O) $\mathrm{Fe}(\mathrm{II})$ formed while growing on $0.5 \mathrm{mM}$ palmitate; $(O) \mathrm{Fe}(\mathrm{II})$ formed in the absence of palmitate; $(\boldsymbol{A})$ increase in cell density while growing on $0.5 \mathrm{mM}$ palmitate; $(\triangle)$ increase in cell density in the absence of palmitate. Data presented are representative of triplicate determinations. 


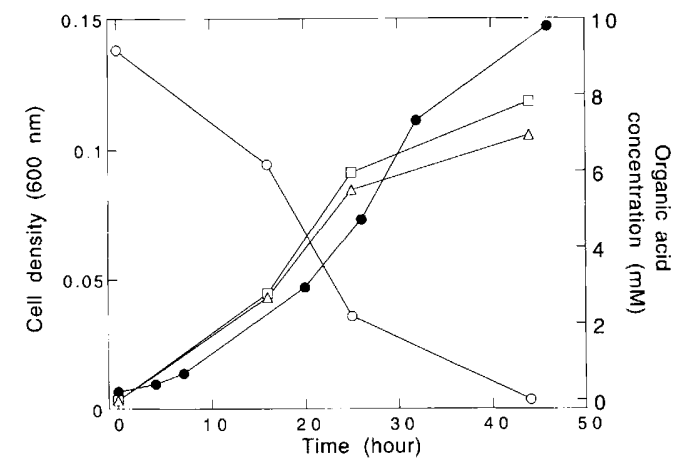

Fig. 3. Growth, citrate removal and acetate and succinate production by strain $\mathrm{H}-5^{\top}$ during fermentation of citrate. (O) Optical density at $600 \mathrm{~nm}$; (O) citrate concentration during growth; $\square$ ) acetate production during fermentation of citrate; $(\triangle)$ succinate production during fermentation of citrate. Data presented are representative of triplicate determinations.

(Coates et al., 1996). However, growth of fermentative micro-organisms is also stimulated on iron(III) pyrophosphate because of the organic compounds included by the manufacturer as chelating agents (Coates et al., 1996). Individual Fe(III)-reducing colonies that were small (about $0.5 \mathrm{~mm}$ diameter) were picked and transferred to fresh basal medium with acetate and iron(III) pyrophosphate as the electron donor and acceptor, respectively. Fully grown cultures of these picked colonies were restreaked onto agar plates of acetate/ iron(III) pyrophosphate medium, from which several morphologically identical isolates were obtained. One of these isolates, strain $\mathrm{H}-5^{\mathrm{T}}$, was selected for further characterization.

\section{Cell and colony morphology}

Cells of strain $\mathrm{H}-5^{\mathrm{T}}$ were non-motile, non-sporeforming rods, $1-2 \times 0.1 \mu \mathrm{m}$ (Fig. 1). Flagella were not detected. Colonies grown on iron(III) pyrophosphate medium were typically less than $1 \mathrm{~mm}$ in diameter. Colonies were white and domed and appeared to be coated with an $\mathrm{Fe}$ (II) mineral, presumably vivianite $\left[\mathrm{Fe}_{3}\left(\mathrm{PO}_{4}\right)_{2} \cdot 8 \mathrm{H}_{2} \mathrm{O}\right]$, similar to that observed for Geobacter species grown on the same medium (Coates $e t$ al., 1996). When growing on fumarate medium, the colonies were red, domed, entire, smooth and wet, which is also similar to colonies of Geobacter species grown on the same medium (J. D. Coates, unpublished). In liquid medium with $\mathrm{Fe}(\mathrm{III})$, strain $\mathrm{H}-5^{\mathrm{T}}$ appeared as single cells or short chains of two to three cells each. In liquid medium with fumarate as the sole electron acceptor, strain $\mathrm{H}-5^{\mathrm{T}}$ grew in long, intertwined, hair-like chains of several hundred cells.

\section{Electron donors and acceptors and growth conditions}

In addition to acetate, strain $\mathrm{H}-5^{\mathrm{T}}$ grew with a variety of organic acids including propionate, lactate, succinate and fumarate as alternative electron donors with $\mathrm{Fe}$ (III) as the sole electron acceptor (Table 1). Strain $\mathrm{H}-5^{\mathrm{T}}$ also coupled growth to the oxidation of palmitate with $\mathrm{Fe}(\mathrm{III})$ serving as the sole electron acceptor (Fig. 2). No organic acids were detected when

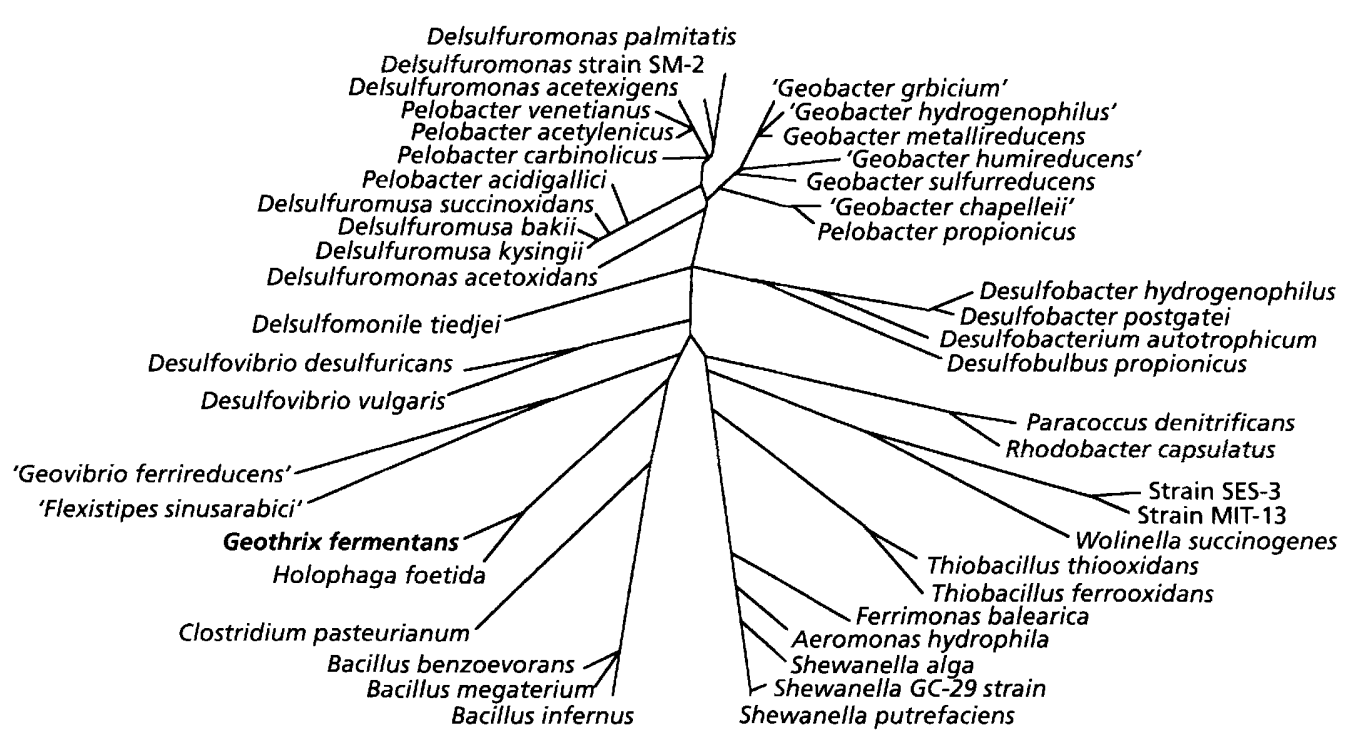

1.00

Fig. 4. Phylogenetic tree inferred from $16 \mathrm{~S}$ rRNA sequences showing the placement of Geothrix fermentans strain $\mathrm{H}-5^{\top}$. The tree was inferred by the distance-matrix method and 1125 positions were considered. Clostridium pasteurianum is the outgroup. The bar represents one evolutionary distance unit. 
culture broths of strain $\mathrm{H}-5^{\mathrm{T}}$ grown on palmitate/ $\mathrm{Fe}(\mathrm{III})$ medium were analysed by HPLC, suggesting that palmitate was completely mineralized to $\mathrm{CO}_{2}$. Yeast extract also served as an electron donor for $\mathrm{Fe}(\mathrm{III})$ reduction by strain $\mathrm{H}-5^{\mathrm{T}}$. A variety of other potential electron donors were not utilized (Table 1).

In addition to iron(III) pyrophosphate, strain $\mathrm{H}-5^{\mathrm{T}}$ could grow with other forms of Fe(III) including iron(III) NTA, iron(III) citrate and poorly crystalline iron(III) oxide. Other electron acceptors used by strain $\mathrm{H}-5^{\mathrm{T}}$ with lactate as the electron donor included $\mathrm{NO}_{3}, \mathrm{Mn}(\mathrm{IV})$, the humic acid analogue AQDS and fumarate. No growth or reduction was observed with elemental sulfur or any of the sulfur anions tested (Table 1). Similarly, strain $\mathrm{H}-5^{\mathrm{T}}$ did not grow aerobically, even under low partial pressures of $\mathrm{O}_{2}(100$ $\mathrm{Pa})$.

In addition to anaerobic respiration, strain $\mathrm{H}-5^{\mathrm{T}}$ could also grow fermentatively on organic acids such as citrate or fumarate. Acetate and succinate were the primary end-products of citrate fermentation (Fig. 3).

Strain $\mathrm{H}-5^{\mathrm{T}}$ grew optimally between 35 and $40^{\circ} \mathrm{C}$ (data not shown); no growth was observed at $25^{\circ} \mathrm{C}$ or lower.

\section{Cytochrome content}

Oxidized versus reduced spectra of washed whole-cell suspensions of strain $\mathrm{H}-5^{\mathrm{T}}$ that had been grown in lactate/fumarate medium indicated absorbance maxima at 552, 524 and $423 \mathrm{~nm}$, which are indicative of a $c$-type cytochrome(s).

\section{Phylogeny of strain $\mathrm{H}^{-5^{\top}}$}

Phylogenetic analysis of the almost complete $16 \mathrm{~S}$ rDNA sequence of strain $\mathrm{H}-5^{\mathrm{T}}$ indicated that it belongs to a distinct, novel line of descent within the domain Bacteria, and places it within the recently described Holophaga-Acidobacterium phylum (Ludwig et al., 1997) (Fig. 4). The closest known cultured relative of strain $\mathrm{H}-5^{\mathrm{T}}$, Holophaga foetida, has $94.3 \%$ sequence identity to strain $\mathrm{H}-5^{\mathrm{T}}$ over 1432 unambiguously aligned positions (Fig. 4).

\section{DISCUSSION}

Strain $\mathrm{H}-5^{\mathrm{T}}$ is phylogenetically unique among microorganisms that have the ability to conserve energy for growth from the reduction of $\mathrm{Fe}(\mathrm{III})$. It is only the second dissimilatory $\mathrm{Fe}$ (III)-reducing micro-organism that does not fall within the family Geobacteraceae and has been shown to oxidize multicarbon organic compounds completely to $\mathrm{CO}_{2}$. The only other complete oxidizer described outside the Geobacteraceae is 'Geovibrio ferrireducens', which, along with 'Flexistippes sinusarabici', is part of novel lineage within the Bacteria (Caccavo et al., 1996).

Strain $\mathrm{H}-5^{\mathrm{T}}$ and closely related organisms represent a recently recognized phylum among the known major bacterial lines of descent (Ludwig et al., 1997). Numerous $16 \mathrm{~S} \mathrm{rDNA}$ sequences recovered from a variety of soils fall within this lineage, but to date the anaerobic acetogen Holophaga foetida (Bak et al., 1992; Liesack \& Finster, 1994) and the aerobic Acidobacterium capsulatum (Hiraishi et al., 1995) are the only organisms other than strain $\mathrm{H}-5^{\mathrm{T}}$ that are available in culture. Attempts to grow Holophaga foetida and Acidobacterium capsulatum with $\mathrm{Fe}(\mathrm{III})$ as the electron acceptor have not been successful.

The phylogenetic and physiological differences between the dissimilatory $\mathrm{Fe}(\mathrm{III})$ reducer strain $\mathrm{H}-5^{\mathrm{T}}$ and the acetogen Holophag a foetida support the placement of strain $\mathrm{H}-5^{\mathrm{T}}$ in a new genus and species within the Holophaga-Acidobacterium phylum. The name Geothrix fermentans gen. nov., sp. nov. is proposed.

\section{Comparison with other DIRB}

The ability of strain $\mathrm{H}-5^{\mathrm{T}}$ to oxidize simple organic acids completely to $\mathrm{CO}_{2}$ with $\mathrm{Fe}$ (III) serving as the sole electron acceptor distinguishes it from a variety of other mesophilic Fe(III) reducers, such as species of Shewanella, Ferrimonas, Aeromonas and Bacillus (Lovley et al., 1997), that oxidize organic compounds only incompletely to acetate. Strain $\mathrm{H}-5^{\mathrm{T}}$ is similar to species of Geobacter (Lovley et al., 1993; Caccavo et al., 1994; Coates et al., 1996, 1998a), Desulfuromonas (Roden \& Lovley, 1993; Coates et al., 1995) and Desulfuromusa (Liesack et al., 1994) of the Geobacteraceae, as well as 'Geovibrio ferrireducens' (Caccavo et al., 1996), in its ability to conserve energy for growth by the oxidation of acetate with the reduction of $\mathrm{Fe}$ (III). Strain $\mathrm{H}-5^{\mathrm{T}}$ can also conserve energy for growth by the oxidation of palmitate, which is similar to 'Desulfuromonas palmitatis' (Coates et al., 1995) but contrasts with all other known Fe(III) reducers (Lovley et al., 1997). Strain $\mathrm{H}-5^{\mathrm{T}}$ is the first freshwater example of a micro-organism that can grow by the oxidation of a long-chain fatty acid with $\mathrm{Fe}$ (III) as the electron acceptor.

In contrast to many dissimilatory $\mathrm{Fe}(\mathrm{III})$ reducers, including Geobacter sulfurreducens (Caccavo et al., 1994), Desulfuromonas species (Pfennig \& Biebl, 1976; Coates et al., 1995), Desulfuromusa species (Liesack et al., 1994), Shewanella putrefaciens (Moser \& Nealson, 1996) and many of the hyperthermophilic Fe(III) reducers (Vargas et al., 1998), strain $\mathrm{H}-5^{\mathrm{T}}$ did not couple growth to the reduction of elemental sulfur. However, other DIRB such as Geobacter metallireducens (Lovley et al., 1993), 'Geobacter hydrogenophilus' and 'Geobacter chapelleii' (Coates et al., 1996) also couple acetate oxidation to the reduction of elemental sulfur, but do not grow well in media with acetate as the sole electron donor and elemental sulfur as the sole electron acceptor.

Similarly to the Desulfuromusa species (Finster \& Bak, 1993; Liesack et al., 1994), strain H-5 ${ }^{\mathrm{T}}$ can also grow 
by the fermentation of simple organic acids such as citrate or fumarate in the absence of a suitable electron acceptor. Although it has been reported that Desulfuromonas species can similarly grow by fermentation of fumarate or malate, this metabolism will only occur at low bicarbonate $/ \mathrm{CO}_{2}$ concentrations (Widdel, 1988).

Like most known mesophilic DIRB, strain $\mathrm{H}-5^{\mathrm{T}}$ contains a $c$-type cytochrome(s). Previous studies have indicated the involvement of $c$-type cytochromes in the transfer of electrons to Fe(III) in Geobacter, Desulfuromonas and Shewanella species (Lovley et al., 1997, and references therein). However, the discovery that Pelobacter species, which do not contain cytochromes, can grow by the reduction of Fe(III) (Lovley et al., 1995) indicates that the presence of $c$-type cytochromes is not necessary for dissimilatory $\mathrm{Fe}$ (III) reduction.

\section{Environmental and evolutionary significance}

Although strain $\mathrm{H}-5^{\mathrm{T}}$ was recovered from aquifer sediments in which $\mathrm{Fe}(\mathrm{III})$ reduction was stimulated with the addition of toluene and NTA, dissimilatory $\mathrm{Fe}$ (III)-reducing organisms closely related to $\mathrm{H}-5^{\mathrm{T}}$ have been recovered from freshly collected sediments from the $\mathrm{Fe}$ (III)-reduction zone of another petroleumcontaminated aquifer (Anderson et al., 1998). In studies in which acetate-oxidizing DIRB were enumerated via culturing, organisms closely related to strain $\mathrm{H}-5^{\mathrm{T}}$ were as numerous in the $\mathrm{Fe}(\mathrm{III})$-reducing zone of the aquifer as Geobacter species (Anderson $e t$ $a l ., 1998)$. Furthermore, in a nearby uncontaminated portion of the aquifer, organisms closely related to $\mathrm{H}-5^{\mathrm{T}}$ were the dominant acetate-oxidizing $\mathrm{Fe}(\mathrm{III})$ reducers recovered. These results contrast with previous studies on aquatic sediments and aquifers (Coates et al., 1996), which suggested that organisms in the Geobacteraceae are the most common acetateoxidizing $\mathrm{Fe}$ (III) reducers that can be recovered in culture. Further studies that use molecular approaches that avoid culture bias will be necessary in order to determine the true relative distribution of Geobacteraceae and organisms related to strain $\mathrm{H}-5^{\mathrm{T}}$ in a variety of sedimentary environments.

Geological evidence, as well as the fact that a variety of hyperthermophilic Archaea and Bacteria have the ability to reduce $\mathrm{Fe}(\mathrm{III})$, suggests that $\mathrm{Fe}$ (III) reduction was one of the earliest forms of microbial respiration (Caccavo et al., 1996; Vargas et al., 1998). If so, it might be expected that the capacity for $\mathrm{Fe}$ (III) reduction would be widely distributed throughout the Bacteria. Although initial studies on DIRB indicated that the micro-organisms that could conserve energy to support growth from $\mathrm{Fe}$ (III) reduction were all Proteobacteria (Lovley et al., 1997), continued study of the diversity of dissimilatory $\mathrm{Fe}$ (III) reducers has now indicated that the capacity for Fe(III) reduction is in fact widespread among phylogenetically diverse organisms (Lovley et al., 1989b, 1997; Rossello-Mora et al., 1994; Boone et al., 1995; Caccavo et al., 1996; Greene et al., 1997; Slobodkin et al., 1997; Coates et al., 1998b). The discovery of dissimilatory Fe(III) reducers in the new Holophaga-Acidobacterium phylum continues this trend.

\section{Description of Geothrix gen. nov.}

Geothrix (Ge'o.thrix. Gr. n. gea Earth; Gr. fem. n. thrix hair; M.L. fem. n. Geothrix hair-like cell from the earth).

Rod-shaped cells, $1-2 \times 0 \cdot 1 \mu \mathrm{m}$, non-motile, nonspore-forming. Cells occur singly or in chains. Strictly anaerobic chemo-organotroph that oxidizes acetate with $\mathrm{Fe}(\mathrm{III})$ serving as the sole electron acceptor. Cells grown with $\mathrm{Fe}(\mathrm{III})$ or fumarate as an electron acceptor contain a $c$-type cytochrome(s).

\section{Description of Geothrix fermentans sp. nov.}

Geothrix fermentans (fer.men'tans. L. part. adj. fermentans fermenting).

Geothrix fermentans can use Mn(IV), nitrate, 2,6anthraquinone disulfonate or fumarate as alternative electron acceptors. Propionate, palmitate, lactate, fumarate or succinate serve as alternative electron donors with $\mathrm{Fe}(\mathrm{III})$ as the electron acceptor. In the absence of a suitable electron acceptor, growth is possible by fermentation of citrate or fumarate. Acetate and succinate are the primary end-products of citrate fermentation. Optimum growth temperature is $35^{\circ} \mathrm{C}$. The type strain of Geothrix fermentans, strain $\mathrm{H}-5^{\mathrm{T}}$, has been deposited in the American Type Culture Collection as ATCC $700665^{\mathrm{T}}$. Geothrix fermentans strain $\mathrm{H}-5^{\mathrm{T}}$ was isolated from sediment samples from a petroleum-contaminated aquifer at Hanahan, SC, USA, that had been enriched for anaerobic toluene oxidation.

\section{ACKNOWLEDGEMENTS}

Support to J.D.C. was provided by grant $98 \mathrm{I}-13$ from the Illinois Council on Food and Agriculture Research. Support to D.R.L. was provided by the National Science Foundation, grant DEB9523932.

\section{REFERENCES}

Anderson, R. T., Rooney-Varga, J. N., Gaw, C. V. \& Lovley, D. R. (1998). Anaerobic benzene oxidation in the Fe(III) reduction zone of petroleum-contaminated aquifers. Environ Sci Technol 32, 1222-1229.

Bak, F., Finster, K. \& Rothfub, F. (1992). Formation of dimethylsulfide and methanethiol from methoxylated aromatic compounds and inorganic sulfide by newly isolated anaerobic bacteria. Arch Microbiol 157, 529-534.

Balch, W. E., Fox, G. E., Magrum, L. J., Woese, C. R. \& Wolfe, R. S. (1979). Methanogens: reevaluation of a unique biological group. Microbiol Rev 43, 260-296. 
Boone, D. R., Liu, Y., Zhao, Z.-J., Balkwill, D. L., Drake, G. R., Stevens, T. O. \& Aldrich, H. C. (1995). Bacillus infernus sp. nov., an Fe(III)- and $\mathrm{Mn}$ (IV)-reducing anaerobe from the deep terrestrial subsurface. Int J Syst Bacteriol 45, 441-448.

Caccavo, F., Jr, Blakemore, R. P. \& Lovley, D. R. (1992). A hydrogen-oxidizing, Fe(III)-reducing microorganism from the Great Bay Estuary, New Hampshire. Appl Environ Microbiol 58, 3211-3216.

Caccavo, F., Jr, Lonergan, D. J., Lovley, D. R., Davis, M., Stolz, J. F. \& McInerney, M. J. (1994). Geobacter sulfurreducens sp. nov., a hydrogen- and acetate-oxidizing dissimilatory metal-reducing microorganism. Appl Environ Microbiol 60, 3752-3759.

Caccavo, F., Jr, Coates, J. D., Rossello-Mora, R. A., Ludwig, W., Schleifer, K. H., Lovley, D. R. \& Mclnerney, M. J. (1996). Geovibrio ferrireducens, a phylogenetically distinct dissimilatory Fe(III)reducing bacterium. Arch Microbiol 165, 370-376.

Cline, J. D. (1969). Spectrophotometric determination of hydrogen sulfide in natural waters. Limnol Oceanogr 14, 454458.

Coates, J. D., Lonergan, D. J., Phillips, E. J. P., Jenter, H. \& Lovley, D. R. (1995). Desulfuromonas palmitatis sp. nov., a marine dissimilatory $\mathrm{Fe}(\mathrm{III})$ reducer that can oxidize long-chain fatty acids. Arch Microbiol 164, 406-413.

Coates, J. D., Phillips, E. J. P., Lonergan, D. J., Jenter, H. \& Lovley, D. R. (1996). Isolation of Geobacter species from diverse sedimentary environments. Appl Environ Microbiol 62, 1531-1536.

Coates, J. D., Ellis, D. J., Blunt-Harris, E. L., Gaw, C. V., Roden, E. E. \& Lovley, D. R. (1998a). Recovery of humic-reducing bacteria from a diversity of environments. Appl Environ Microbiol 64, 1504-1509.

Coates, J. D., Councell, T., Lovley, D. R. \& Lonergan, D. J. (1998b). Carbohydrate oxidation coupled to Fe(III) reduction, a novel form of anaerobic metabolism. Anaerobe (in press).

Coleman, M. L., Hedrick, D. B., Lovley, D. R., White, D. C. \& Pye, K. (1993). Reduction of $\mathrm{Fe}(\mathrm{III})$ in sediments by sulphatereducing bacteria. Nature 361, 436-438.

De Soete, G. (1983). A least squares algorithm for fitting additive trees to proximity data. Psychometrika 48, 621-626.

Finster, K. \& Bak, F. (1993). Complete oxidation of propionate, valerate, succinate, and other organic compounds by newly isolated types of marine, anaerobic, mesophilic, gram-negative, sulfur-reducing eubacteria. Appl Environ Microbiol 59, 1452-1460.

Greene, A. C., Patel, B. K. C. \& Sheehy, A. J. (1997). Deferribacter thermophilus gen. nov., sp. nov., a novel thermophilic manganese- and iron-reducing bacterium isolated from a petroleum reservoir. Int $J$ Syst Bacteriol 47, 505-509.

Hiraishi, A., Kishimoto, N., Kosako, Y., Wakao, N. \& Tano, T. (1995). Phylogenetic position of the menaquinone-containing acidophilic chemo-organotroph Acidobacterium capsulatum. FEMS Microbiol Lett 132, 91-94.

Hobbie, J. E., Daley, R. J. \& Jasper, S. (1977). Use of nuclepore filters for counting bacteria by fluorescence microscopy. Appl Environ Microbiol 33, 1225-1228.

Hungate, R. E. (1969). A roll tube method for cultivation of strict anaerobes. Methods Microbiol 3B, 117-132.

Jukes, T. H. \& Cantor, C. R. (1969). Evolution of protein molecules. In Mammalian Protein Metabolism, pp. 21-132. Edited by H. N. Munro. New York: Academic Press.

Laverman, A., Switzer Blum, J., Schaefer, J. K., Phillips, E. J., Lovley, D. R. \& Oremland, R. (1995). Growth of strain SES-3 with arsenate and other diverse electron acceptors. Appl Environ Microbiol 61, 3556-3561.
Liesack, W. \& Finster, K. (1994). Phylogenetic analysis of five strains of gram-negative, obligately anaerobic, sulfur-reducing bacteria and description of Desulfuromusa gen. nov., including Desulfuromusa kysingii sp. nov., Desulfuromusa bakii sp. nov., and Desulfuromusa succinoxidans sp. nov. Int $J$ Syst Bacteriol 44, 753-758.

Liesack, W., Bak, F., Kreft, J. U. \& Stackebrandt, E. (1994). Holophaga foetida gen. nov., sp. nov., a new, homoacetogenic bacterium degrading methoxylated aromatic compounds. Arch Microbiol 162, 85-90.

Lonergan, D. J., Jenter, H. L., Coates, J. D., Phillips, E. J.P., Schmidt, T. M. \& Lovley, D. R. (1996). Phylogenetic analysis of dissimilatory $\mathrm{Fe}(\mathrm{III})$-reducing bacteria. J Bacteriol 178, 2402-2408.

Lovley, D. R. (1991). Dissimilatory Fe(III) and Mn(IV) reduction. Microbiol Rev 55, 259-287.

Lovley, D. R. (1995). Microbial reduction of iron, manganese, and other metals. Adv Agron 54, 175-231.

Lovley, D. R. (1997). Potential for anaerobic bioremediation of BTEX in petroleum-contaminated aquifers. J Ind Microbiol 18, 75-81.

Lovley, D. R. \& Phillips, E. J.P. (1986). Organic matter mineralization with reduction of ferric iron in anaerobic sediments. Appl Environ Microbiol 51, 683-689.

Lovley, D. R. \& Phillips, E. J. P. (1988a). Manganese inhibition of microbial iron reduction in anaerobic sediments. Geomicrobiol $J$ 6, 145-155.

Lovley, D. R. \& Phillips, E. J. P. (1988b). Novel mode of microbial energy metabolism: organic carbon oxidation coupled to dissimilatory reduction of iron or manganese. Appl Environ Microbiol 54, 1472-1480.

Lovley, D. R. \& Phillips, E. J. P. (1989). Requirement for a microbial consortium to completely oxidize glucose in Fe(III)reducing sediments. Appl Environ Microbiol 55, 3234-3236.

Lovley, D. R., Stolz, J. F., Nord, G. L. \& Phillips, E. J. P. (1987). Anaerobic production of magnetite by a dissimilatory ironreducing microorganism. Nature 330, 252-254.

Lovley, D. R., Baedecker, M. J., Lonergan, D. J., Cozzarelli, I. M., Phillips, E. J. P. \& Siegel, D. I. (1989a). Oxidation of aromatic contaminants coupled to microbial iron reduction. Nature $\mathbf{3 3 9}$, 297-299.

Lovley, D. R., Phillips, E. J. P. \& Lonergan, D. J. (1989b). Hydrogen and formate oxidation coupled to dissimilatory reduction of iron or manganese by Alteromonas putrefaciens. Appl Environ Microbiol 55, 700-706.

Lovley, D. R., Giovannoni, S. J., White, D. C., Champine, J. E., Phillips, E. J. P., Gorby, Y. A. \& Goodwin, S. (1993). Geobacter metallireducens gen. nov. sp. nov., a microorganism capable of coupling the complete oxidation of organic compounds to the reduction of iron and other metals. Arch Microbiol 159, 336-344.

Lovley, D. R., Chapelle, F. H. \& Woodward, J. C. (1994a). Use of dissolved $\mathrm{H}_{2}$ concentrations to determine the distribution of microbially catalyzed redox reactions in anoxic groundwater. Environ Sci Technol 28, 1205-1210.

Lovley, D. R., Woodward, J. C. \& Chapelle, F. H. (1994b). Stimulated anoxic biodegradation of aromatic hydrocarbons using Fe(III) ligands. Nature 370, 128-131.

Lovley, D. R., Phillips, E. J. P., Lonergan, D. J. \& Widman, P. K. (1995). Fe(III) and $S^{0}$ reduction by Pelobacter carbinolicus. Appl Environ Microbiol 61, 2132-2138.

Lovley, D. R., Coates, J. D., Blunt-Harris, E. L., Phillips, E. J. P. \& 
Woodward, J. C. (1996). Humic substances as electron acceptors for microbial respiration. Nature 382, 445-448.

Lovley, D. R., Coates, J. D., Saffarini, D. \& Lonergan, D. J. (1997). Diversity of dissimilatory Fe(III)-reducing bacteria. In Iron and Related Transition Metals in Microbial Metabolism, pp. 187-215. Edited by G. Winkelman \& C. J. Carrano. Chur, Switzerland: Harwood Academic Publishers.

Lovley, D. R., Fraga, J. L., Blunt-Harris, E. L., Hayes, L. A., Phillips, E. J. P. \& Coates, J. D. (1998). Humic substances as a mediator for microbially catalyzed metal reduction. Acta Hydrochim Hydrobiol 26, 152-157.

Ludwig, W., Bauer, S. H., Bauer, M. \& 7 other authors (1997). Detection and in situ identification of representatives of a widely distributed new bacterial phylum. FEMS Microbiol Lett 153, 181-190.

Maidak, B. L., Olsen, G. J., Larsen, N., Overbeek, R., McCaughey, M. J. \& Woese, C. R. (1997). The RDP (Ribosomal Database Project). Nucleic Acids Res 25, 109-111.

Miller, T. L. \& Wolin, M. J. (1974). A serum bottle modification of the Hungate technique for cultivating obligate anaerobes. Appl Microbiol 27, 985-987.

Moser, D. \& Nealson, K. (1996). Growth of the facultative anaerobe Shewanella putrefaciens by elemental sulfur reduction. Appl Environ Microbiol 62, 2100-2105.

Pfennig, N. \& Biebl, H. (1976). Desulfuromonas acetoxidans gen. nov. and sp. nov., a new anaerobic, sulfur-reducing, acetateoxidizing bacterium. Arch Microbiol 110, 3-12.
Roden, E. E. \& Lovley, D. R. (1993). Dissimilatory Fe(III) reduction by the marine microorganism Desulfuromonas acetoxidans. Appl Environ Microbiol 59, 734-742.

Rossello-Mora, R. A., Caccavo, F., Jr, Osterlehner, K., Springer, N., Spring, S., Schuler, D., Ludwig, W., Amann, R., Vanncanneyt, M. \& Schleifer, K. H. (1994). Isolation and taxonomic characterization of a halotolerant, facultatively iron-reducing bacterium. Syst Appl Microbiol 17, 569-573.

Rossello-Mora, R. A., Ludwig, W., Kampfer, P., Amann, R. \& Schleifer, K. H. (1995). Ferrimonas balearica gen. nov., spec. nov., a new marine facultative Fe(III)-reducing bacterium. Syst Appl Microbiol 18, 196-202.

Slobodkin, A., Reysenbach, A.-L., Strutz, N., Dreier, M. \& Wiegel, J. (1997). Thermoterrabacterium ferrireducens gen. nov., sp. nov., a thermophilic anaerobic dissimilatory $\mathrm{Fe}$ (III)-reducing bacterium from a continental hot spring. Int J Syst Bacteriol 47, 541-547.

Vargas, M., Kashefi, K., Blunt-Harris, E. L. \& Lovley, D. R. (1998). Microbiological evidence for Fe(III) reduction on early Earth. Nature 395, 65-67.

Walker, J. C. G. (1987). Was the Archaean biosphere upside down? Nature 329, 710-712.

Widdel, F. (1988). Microbiology and ecology of sulfate- and sulfur-reducing bacteria. In Biology of Anaerobic Microorganisms, pp. 469-585. Edited by A. J. B. Zehnder. New York: Wiley. 